\title{
(U-Th)/He thermochronology constraints on the Phanerozoic exhumation history of the eastern Pilbara Craton, Australia
}

\author{
By \\ Lane Daigle \\ Department of Geological Sciences, University of Colorado at Boulder
}

April 9, 2020

Thesis Advisor:

Dr. Rebecca M. Flowers

Department of Geological Sciences

Defense Committee:

Dr. Rebecca M. Flowers, Department of Geological Sciences

Dr. Brian M. Hynek, Department of Geological Sciences

Dr. Susan M. Hendrickson, Department of Chemistry 


\section{Acknowledgements:}

I want to thank Dr. Ben Johnson for his superior mentorship. Without his willingness to share this project I would have never experienced such a lifechanging and rewarding endeavor. He has a remarkable ability to be hands off when needed, yet extremely helpful and encouraging at every opportunity. I also want to thank Dr. Becky Flowers. Without her none of this would have been possible. Dr. Flower's work in putting together the thermochronology lab has been an incredible force for the department of geological sciences at CU Boulder. Her willingness to open her lab to the many undergraduate students has made a it a dream environment for students to explore the world of science. I especially want to thank Dr. Jim Metcalf; he has set the bar extremely high for lab managers as his dedication to the craft is boundless. He has been with me since my genesis with this lab group and his carful training has been the absolute reason for my success. I finally want to thank the CU TRalL lab group, all my professors and all of my fellow students for making my time here at the University of Colorado a special and undeniably invaluable experience. 


\section{Abstract:}

The Pilbara of Western Australia is an Archean craton that has provided key insights into the early Earth, including continental formation, continental emergence, and early evolution of life. However, its younger history of Phanerozoic burial, exhumation, and uplift is poorly understood due to its considerable age and scarcity of published regional low temperature thermochronology data. Here, we present new zircon and apatite, Uranium-Thorium/Helium $((\mathrm{U}-\mathrm{Th}) / \mathrm{He})$ data gathered from multiple Archean granitic intrusions across the Eastern Pilbara Craton. The samples cover an area of 12,000 km², and include intrusions emplaced between 3500 and $2900 \mathrm{Ma}$. They range in composition from true granites to granodiorites with one dolerite. Our preliminary findings indicate regional cooling between 425-370 Ma. An important additional geologic constraint is that the $\sim 2940$ Ma Chillerma granite is unconformably overlain by the Jurassic-Cretaceous Callawa Formation. Together the results imply the Chillerma was exhumed into the near-surface in the Silurian, and was exposed at the surface during the Mesozoic by the time of deposition of the Callawa formation. Previous apatite fission-track studies, from about $200 \mathrm{~km}$ south of the Chillerma, corroborate our interpretation, with Paleozoic cooling around $320 \mathrm{Ma}$ (Weber et al. 2005). The Pilbara Craton had a dynamic and protracted Paleozoic exhumation history. 


\section{Introduction:}

Global Archean craton thermochronology has been an arduous pursuit. This pursuit has been largely limited by complex sample histories. Ambiguous plate reconstructions and paleogeography further confound such efforts. In this thesis, I outline a study focused on constraining the low-temperature thermal history of the Archean Pilbara craton using zircon and apatite (U-Th)/He data obtained in the University of Colorado's Thermochronology Research and Instrumentation Laboratory (TRalL).

The uplift history from emplacement to exposure of the Achaean Pilbara Craton has been poorly constrained. While the Archean history of crustal growth and assembly is reasonably well constrained (Nijman et al., 2017; Kranendonk et al., 2002; Weber et al., 2005), there has been little study of the craton's Phanerozoic history. Lithological, stratigraphic, and structural evidence of exhumation is not easily recognizable, due to the great age of the rock units and preexisting structures. In this study, I present new low temperature zircon and apatite (ZHe and AHe, respectively) (U-Th)/He thermochronometry data for samples from a $12,000 \mathrm{~km}^{2}$ area with compositions from true granites to granodiorites and one dolerite that help to better constrain the exhumation/uplift history of the Pilbara Craton.

\section{Geologic and Tectonic Setting:}

The geology of the Australian continent can be broken into four main geologic regions: Achaean Granite-Greenstone Terranes in the west, Proterozoic orogenic belts 
scattered throughout western and central AU, Paleozoic-Mesozoic orogenic belts in the east, and Proterozoic to Cenozoic sedimentary basin all throughout (Fig. 1). Australia is fundamentally divided by the Tasman Line separating Precambrian blocks to the west from Phanerozoic orogenic belts along the eastern margin (Gleadow et al., 2002). The Pilbara Craton, located in Western Australia, is comprised of two fundamental components: a Paleoarchean to Neoarchean $(3.72-2.85 \mathrm{Ga})$ basement of granitoids surrounded by greenstones in the northern region, which unconformably overlie a volcanic-sedimentary package from the Neoarchean $(2.77-2.40 \mathrm{Ga})$ to the south (Kranendonk, 2002) (Fig. 2). The tectonic processes that formed the craton are still debated (e.g., Smithies et al., 1999; Zegers, 1996). Hypotheses include: 1) an amalgamation of Archaean terranes, which is the case for the Yilgarn Craton immediately to the south, 2) solid-state diapirism (Weber et al., 2004), and 3) phases of plutonism of the granitoids interjected with phases of microplate tectonics (Kranendonk, 2002) (Fig. 2). Regardless of the exact mechanism of formation, the granite-greenstone Pilbara is one of the largest and best exposed Archean regions in the world. The age of these rocks coupled with the low relief of this region has led to some researchers to suggest that the craton has been exposed at approximately its current level for an extended time interval, with little lowering by erosion since perhaps as early as Mesoproterozoic (e.g., Fairbridge and Finkl, 1980). In addition, a valley-fill conglomerate from the Northern Territory in Central Australia formed a depositional surface that has been undisturbed and subaerial since the mid-Cambrian, implying little tectonism since the Neoproterozoic (Weber et al., 2004). 


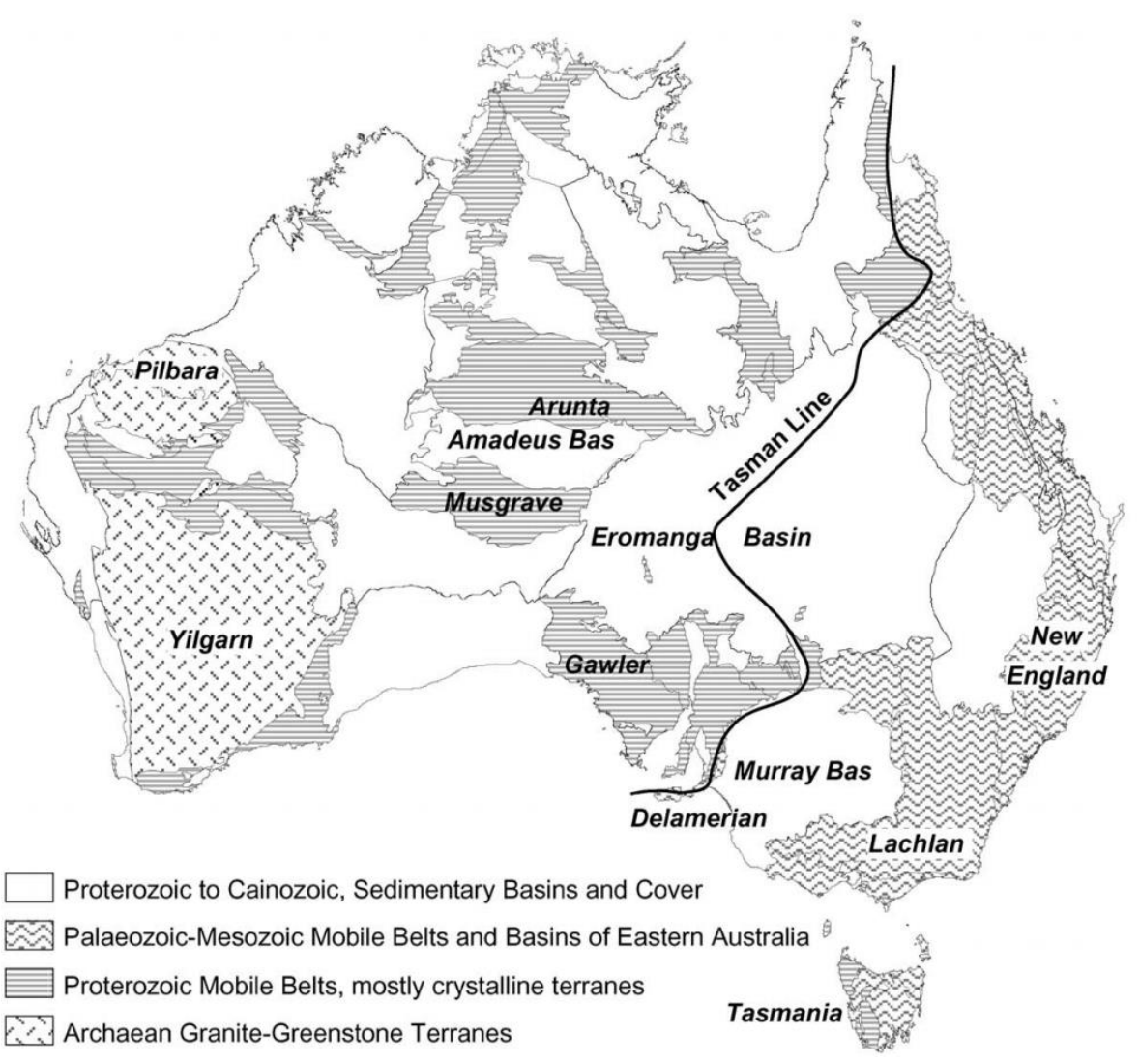

Figure 1: Simplified geologic map of Australia (Gleadow et al., 2002) Showing the major geologic components of the continent along with the Tasman Line.

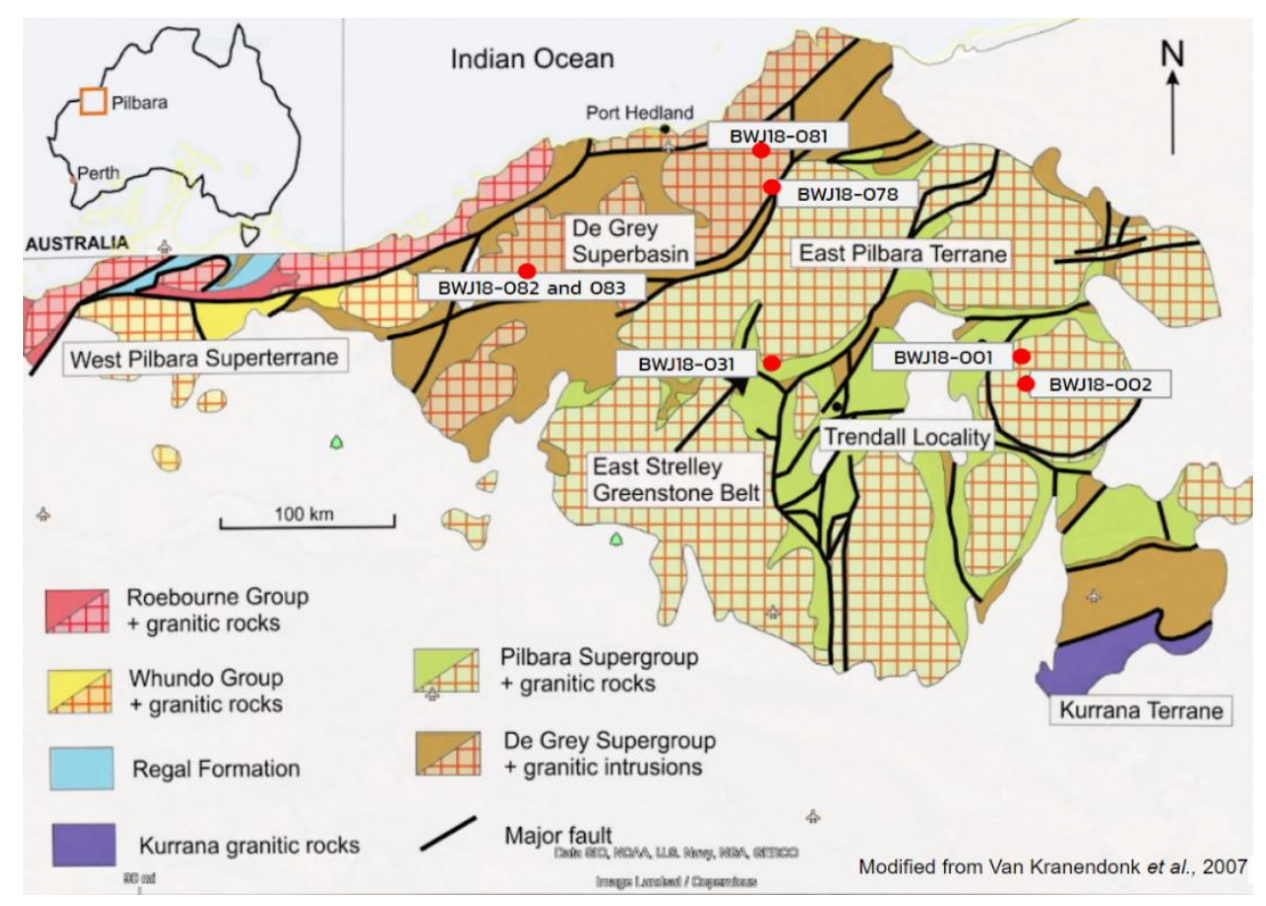

Figure 2: Simplified geologic map of Pilbara Craton (Wacey, 2009) with sample locations. 


\section{Methods and Materials:}

\section{Samples:}

Dr. Benjamin Johnson collected these samples in Western Australia during July of 2018 with the hopes of gathering geochronologic and thermochronologic data. There are a total of six granitic samples and one dolerite that were brought back with him to the University of Colorado. This is where I stepped in for further processing and data gathering for this research project.

Table 1: Sample list with date, location, rock type, and approx. age

\begin{tabular}{|l|l|r|r|l|l|}
\hline $\begin{array}{l}\text { Sample } \\
\text { name }\end{array}$ & $\begin{array}{l}\text { Collection } \\
\text { Date }\end{array}$ & $\begin{array}{l}\text { Latitude (S, } \\
\text { Decimal degrees) }\end{array}$ & $\begin{array}{l}\text { Longitude (E, } \\
\text { decimal degrees) }\end{array}$ & $\begin{array}{l}\text { Rock } \\
\text { type }\end{array}$ & $\begin{array}{l}\text { Crystallization } \\
\text { Age }\end{array}$ \\
\hline BWJ18001 & 18-Jul-18 & 21.09396 & 119.936844 & Granite & 3420-3500 Ma \\
\hline BWJ18002 & $18-J u l-18$ & 21.184638 & 119.955399 & Granite & 3420-3500 Ma \\
\hline BWJ18031 & 22-Jul-18 & 21.1272333 & 119.00985 & Granite & 3469 Ma \\
\hline BWJ18078 & 27-Jul-18 & 20.52047 & 119.03551 & Granite & $2945 \mathrm{Ma}$ \\
\hline BWJ18081 & 27-Jul-18 & 20.37601 & 118.9818 & Granite & $2945 \mathrm{Ma}$ \\
\hline BWJ18082 & 27-Jul-18 & 20.82155 & 118.11475 & Dolerite & $2760 \mathrm{Ma}$ \\
\hline BWJ18083 & 27-Jul-18 & 20.82155 & 118.11475 & Granite & $2946 \mathrm{Ma}$ \\
\hline
\end{tabular}



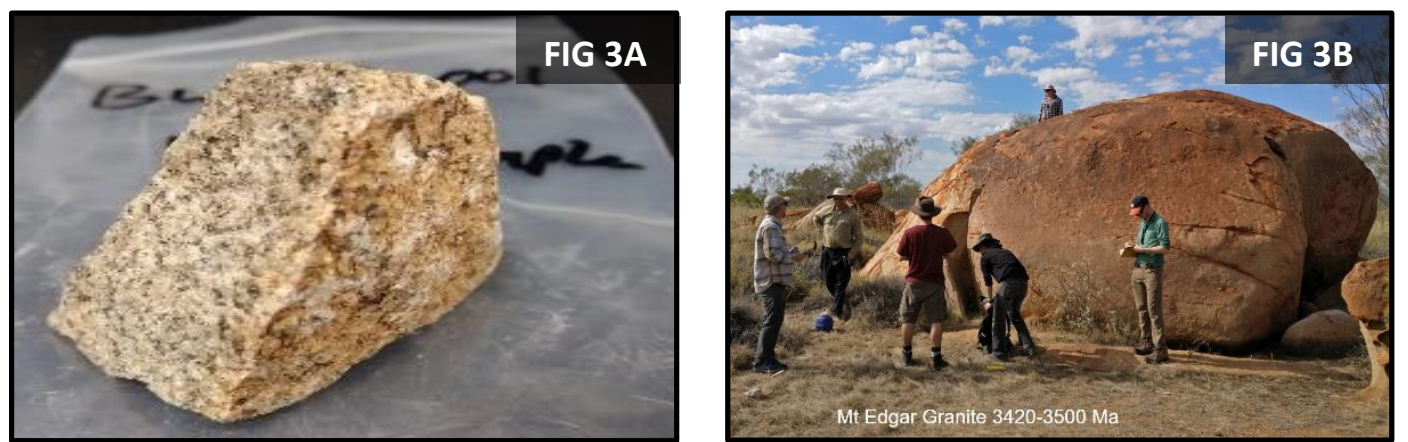

BWJ18-001: Mt. Edgar Granite: Figure 3A and 3B

Granite to granodiorite showing high amounts of plagioclase feldspars and quartz, with potassium feldspar and biotite possibly amphiboles, with a crystallization age around 3420-3500 Ma.
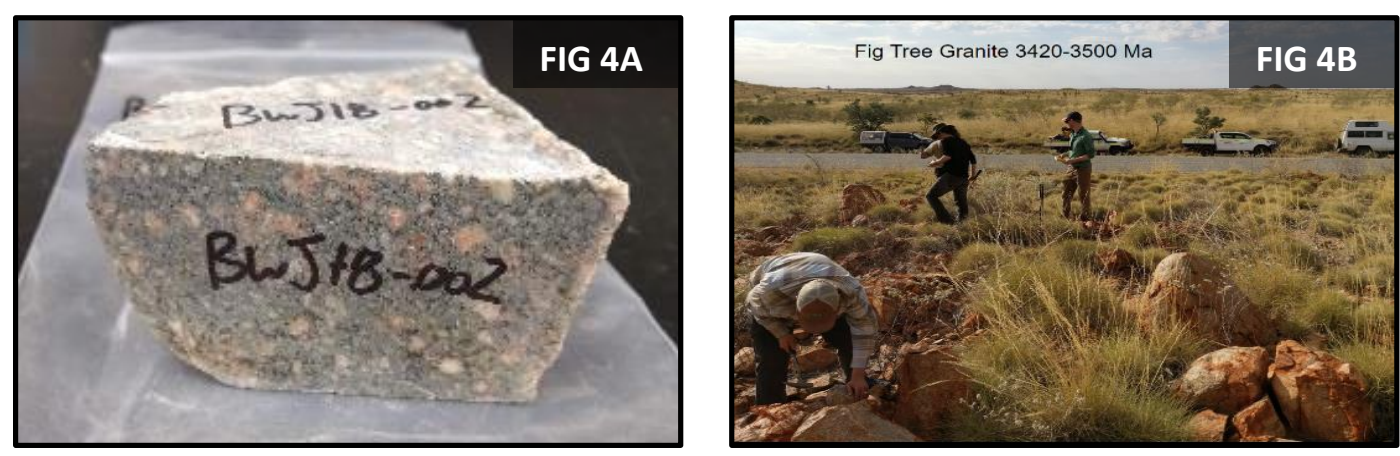

\section{BWJ18-002: Fig Tree Granite: Figure 4A and 4B}

Granite displaying large potassium feldspar crystals, plagioclase feldspar, small but many quartz crystals, as well as biotite and accessory minerals, with a crystallization age of around the same time as the Mt. Edgar Granite 3420-3500 Ma.

\section{BWJ18-031: Callina Granite Super Suite: Figure 5}

Granodiorite showing lots of plagioclase feldspar, biotite, and quartz, mediumcoarse grained with no obvious potassium feldspar, that was found underlying the Strelley Pool formation. This sample has a crystallization age of $3469 \mathrm{Ma}$

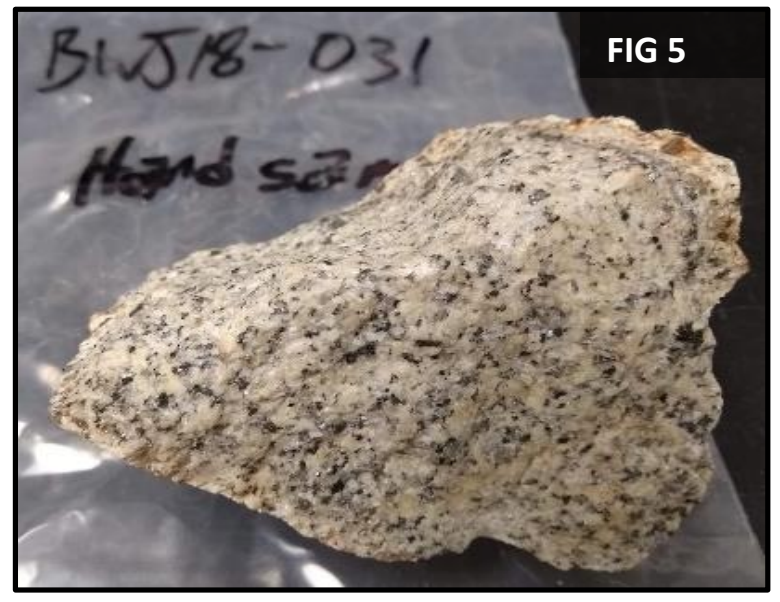



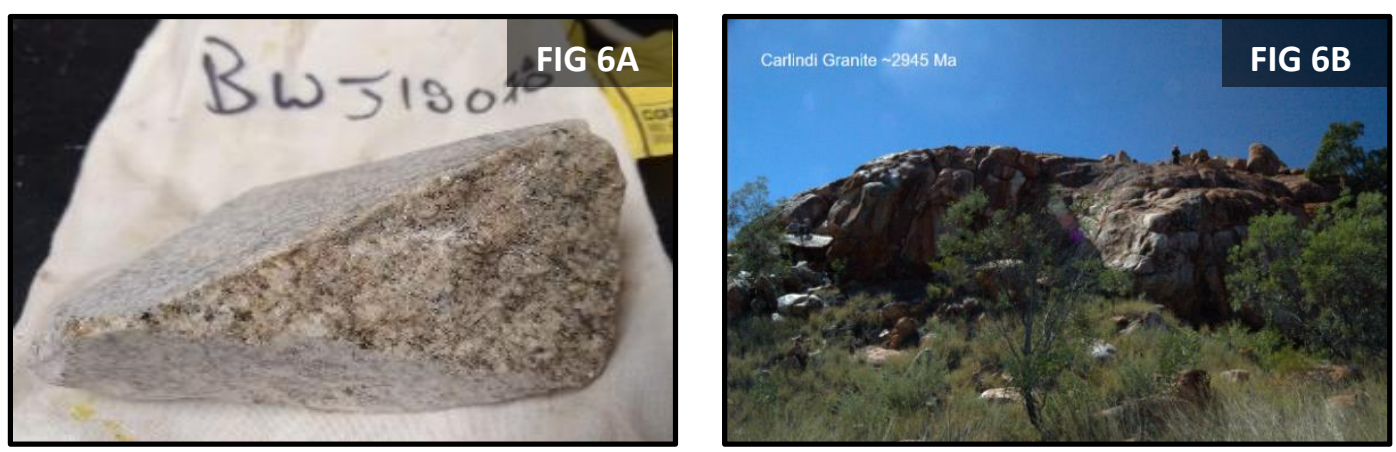

\section{BWJ18-078: Carlindi Granite: Figure 6A and 6B}

Granitoid exhibiting large amounts of quartz, plagioclase feldspar, light potassium feldspar and small amounts of scattered accessory minerals with a crystallization age of $2945 \mathrm{Ma}$.
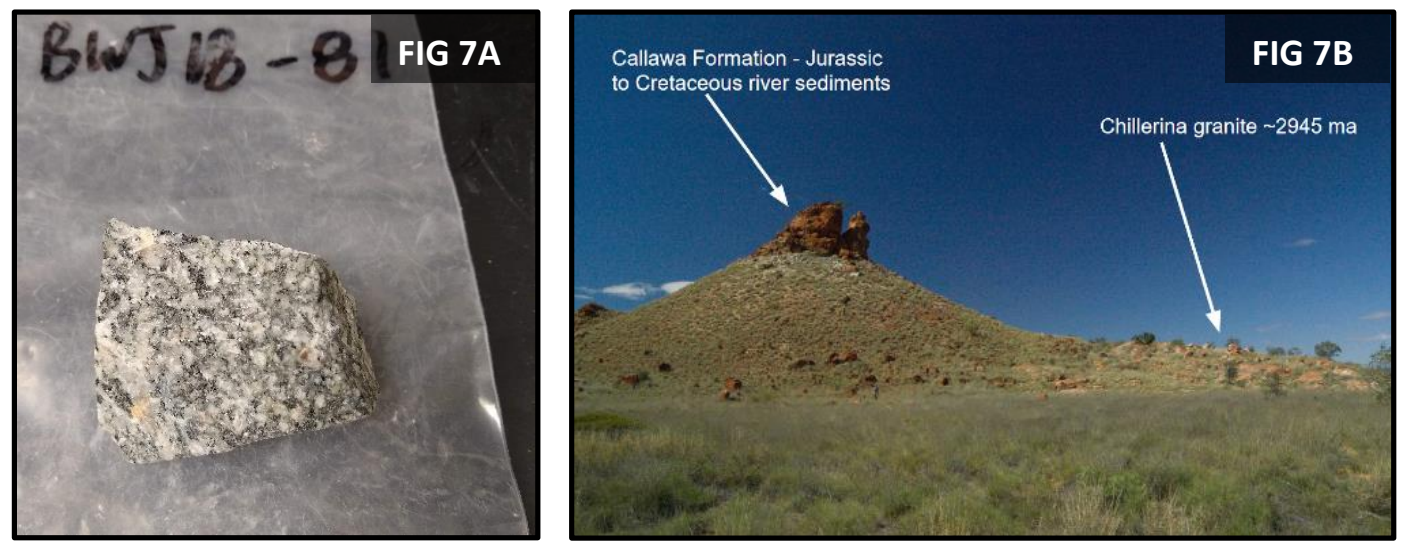

\section{BWJ18-081: Chillerma Granite: Figure 7A and 7B}

This granite has large quartz, plagioclase feldspar crystals, with some small potassium feldspars and biotite. As seen in figure $5 B$, this granite it underlying the callawa formation, a Jurassic to cretaceous sandstone. Same as the Carlindi, this sample has a crystallization age of $2945 \mathrm{Ma}$. 

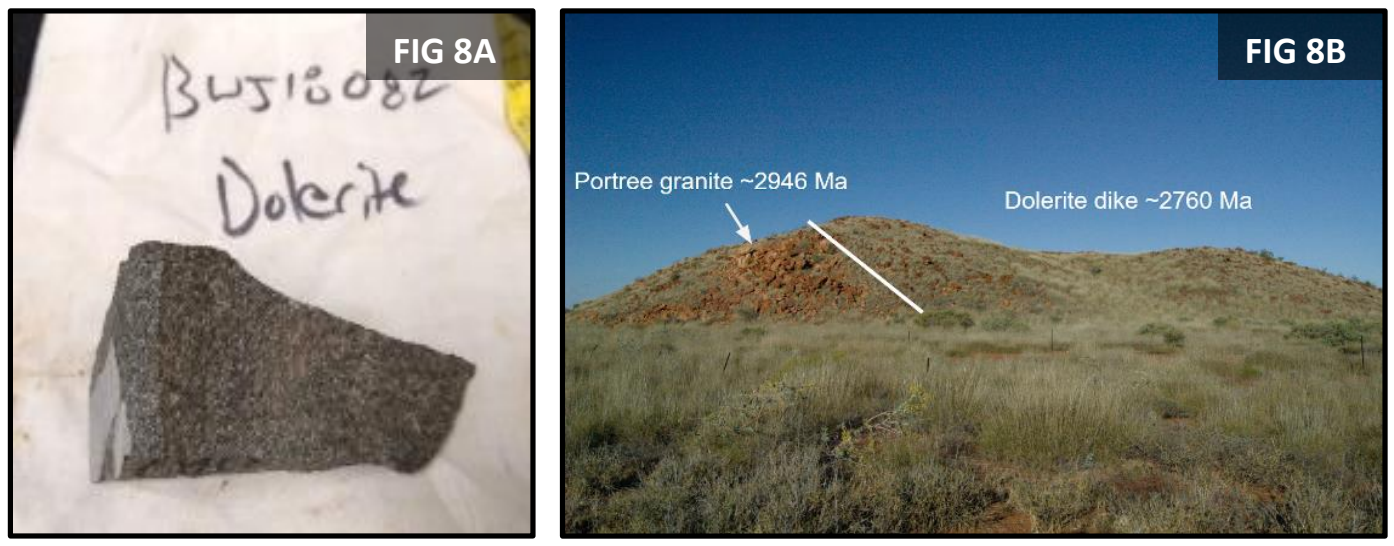

BWJ18-082: Dolerite Dike: Figure 8A and 8B

Small tightly packed crystals of plagioclase feldspar and pyroxene with several accessory minerals. This Dolerite dike is cutting across the older Portree granite shown in figure 6B. The youngest of these samples, this rock has a crystallization age of about $2760 \mathrm{Ma}$.
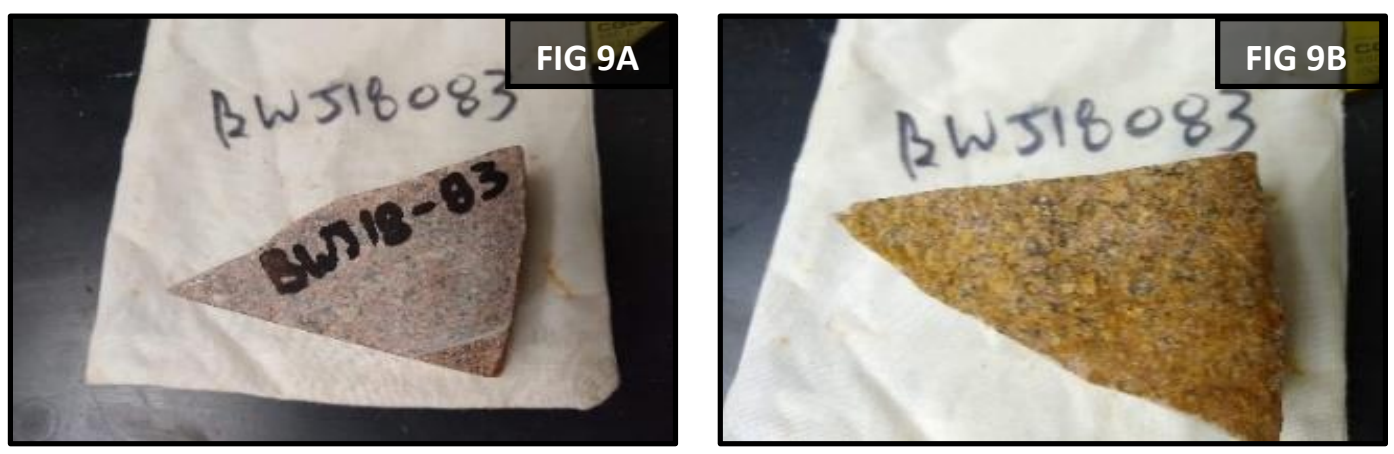

BWJ18-083: Portee Granite: Figure 9A and 9B:

This sample has a similar age to the Carlindi and Chillerma Granites, with a crystallization age around 2946 Ma. A very pink granite showing lots of crystals of potassium feldspar, and some quartz, biotite and other accessory minerals.

\section{Thermochronology Dating Methods:}

$(\mathrm{U}-\mathrm{Th}) / \mathrm{He}$ Thermochronology is based on measuring the accumulation of alpha particles of Helium $4\left({ }^{4} \mathrm{He}\right)$ in mineral samples that are the result from decay of Uranium (U), Thorium (Th), and Samarium (Sm) in minerals. Helium diffuses out of the crystal at a higher temperature and is retained at lower temperatures. This generally means that 
$(\mathrm{U}-\mathrm{Th}) / \mathrm{He}$ dates are cooling ages, and the more ${ }^{4} \mathrm{He}$ a mineral retains, the longer it has been at near surface conditions (low temperature $80-100^{\circ} \mathrm{C}$ or less). This concept is straightforward, but cooling histories can be masked by reburial or reheating events. These events cause the mineral to go above its closure temperature with respect to $\mathrm{He}$, and "reset" the He-clock. Potential reheating events are important to consider, especially in rocks that are as old as those in the Pilbara.

Apatite and zircon are the most commonly used minerals for (U-Th)/He thermochronology, since they are common minerals, have abundant parents $(\mathrm{U}, \mathrm{Th}, \mathrm{Sm})$, and can retain measureable quantities of of $\mathrm{He}$. The production of these alpha particles, ${ }^{4} \mathrm{He}$, is a function of the decay of $238 \mathrm{U}-235 \mathrm{U}-232 \mathrm{Th}$ and can be shown in this age equation:
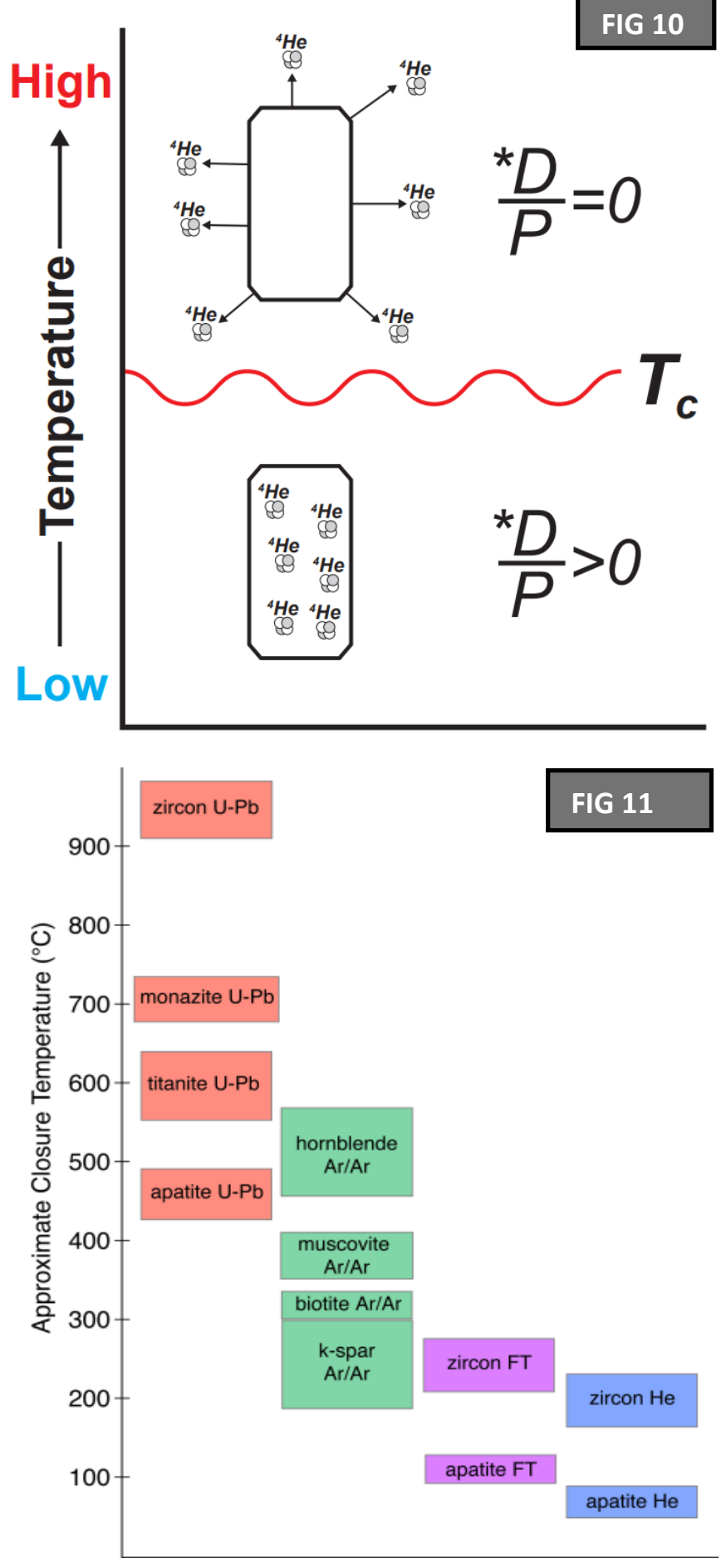

Figures 10 and 11: (Metcalf and Flowers, In Press) Fig. 10 showing parent daughter ratio relationship in relation to closure temperature $\left(T_{c}\right)$ and in Fig. 11 a graph depicting the approx. closure temperatures for a suite of minerals. Notice zircon $\mathrm{He}$ and apatite He in blue boxes to the right, used in this study. 


$$
{ }^{4} \mathrm{He}=8 \times{ }^{238} \mathrm{U}\left(e^{\lambda_{238} t}-1\right)+7 \times{ }^{235} \mathrm{U}\left(e^{\lambda_{235} t}-1\right)+6 \times{ }^{232} \mathrm{Th}\left(e^{\lambda_{232} t}-1\right)+{ }^{147} \mathrm{Sm}\left(e^{\lambda_{147} t}-1\right)
$$

where $t$ is the age or accumulation time, $\lambda$ is the respective decay constant and the $\mathrm{He}, \mathrm{U}, \mathrm{Th}$, and Sm is the amount of atoms in the mineral (Metcalf and Flowers, In Press). Levels of U, Th, and Sm along with daughter product He were measured in apatites and zircons from the collected samples. These data were used to calculate (UTh)/He dates, with the goal of constraining the cooling history of the Pilbara craton. This cooling history can then be related to a variety of geologic processes like erosional exhumation, formation of features, deformation of features and emplacement.

To obtain robust dates from (UTh)/He data, we needed to have a selection of quality individual apatite and zircon minerals. To do this we begin with the hand samples and break them down into individual minerals. This is accomplished by running the samples through the Jaw Crusher and Vertical Disk Grinder-Pulverizer (Fig. 12) in CU Boulder's rock shop, turning the previous whole rock into a mixture

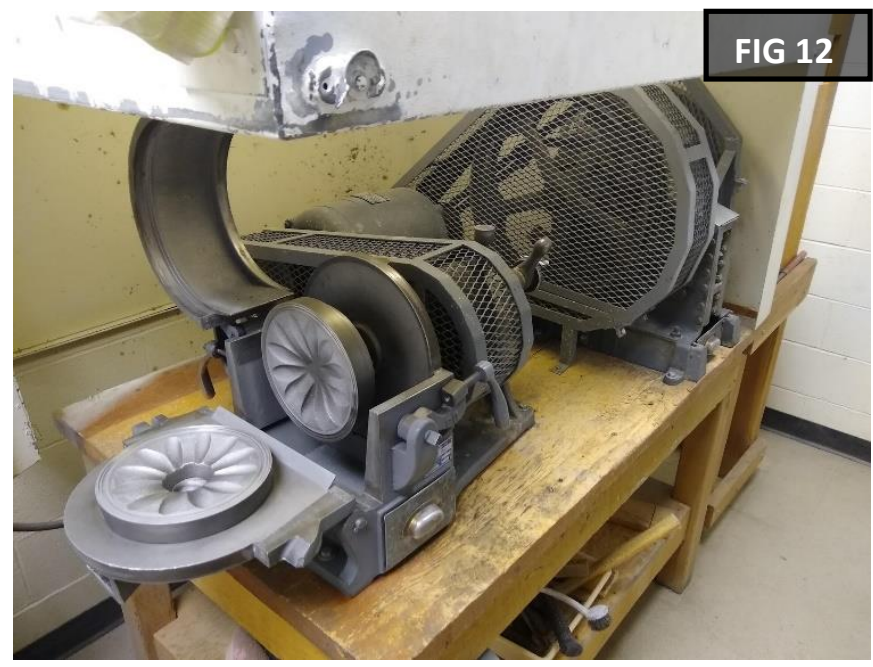

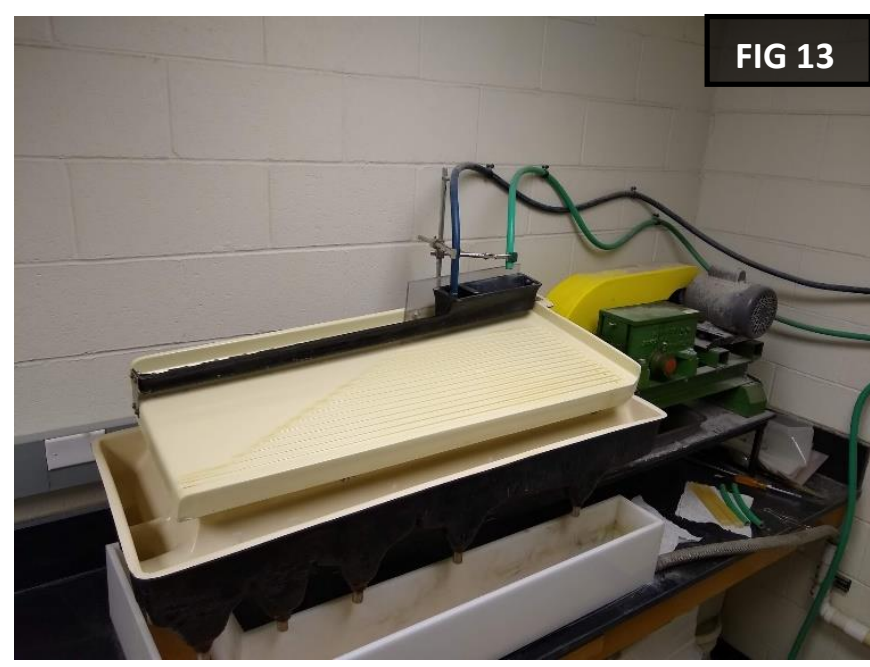

Figure 12: showing CU Boulder's Rock Shop Jaw Crusher and Disk Grinder, and Figure 13: Wilfley Table.

of fine powder to a small gravel. This sample is then sieved through wire mesh to a level of less than or equal to $500 \mu \mathrm{m}$ and following this it is separated hydrodynamically via 
Wilfley Table (Fig. 13) to isolate higher density minerals. Next the sample undergoes a magnetic separation process with first a hand magnet and then through the Frantz Magnetic Separator set to $1.0 \mathrm{Amp}$ and at an angle of $20^{\circ}$. Lastly, with the denser, mostly non-magnetic minerals, the sample is partitioned via heavy liquid separation using Lithium Metatungstate at a specific density around 2.95 $\mathrm{g} / \mathrm{cm}^{3}$.

This final selection of minerals, usually just a tiny pinch, is placed under a Leica binocular microscope for each apatite or zircon mineral (Fig. 14) to be carefully selected and packaged in niobium $(\mathrm{Nb})$ tubes. Selection of minerals are based on size $(>60$ $\mu \mathrm{m})$, the euhedral shape of the crystal, and free of inclusions for apatites especially.

These mineral packages are then loaded into an ASI Alphachron He extraction line (UHV 3x108torr) and subjected to $25 \mathrm{~W}$ diode laser for five to ten minutes, heating the packaged mineral to about 800 to $1100^{\circ} \mathrm{C}$ to extract the radiogenic $4 \mathrm{He}$. Next, the minerals are spiked with a $235 \mathrm{U}-230 \mathrm{Th}-145 \mathrm{Nd}$ tracer and either the apatite is dissolved in $\mathrm{a} \mathrm{HNO}_{3}$ solution or the zircons are dissolved in a multiple acid-vapor dissolution using HF placed in a Parr

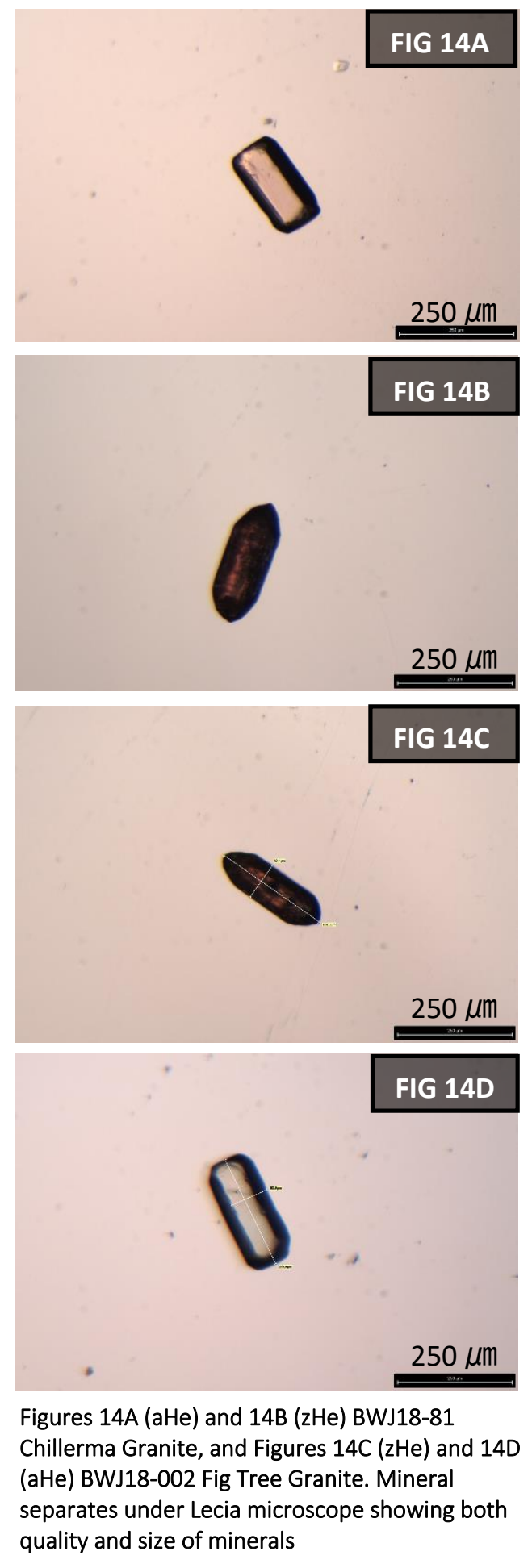


dissolution vessel. After baking $\left(80^{\circ} \mathrm{C}\right.$ at 2 hours for apatites or $220^{\circ} \mathrm{C}$ for 72 hours for zircons) the samples are dried, then placed under another acid-vapor dissolution $\mathrm{HCl}$ and baked again $\left(200^{\circ} \mathrm{C}\right.$ at 24 hours). After the mineral samples are fully dissolved, measurements of $\mathrm{U}$, Th and Sm are analyzed using an Agilent ICP-MS and compared against standards of Durango fluorapatite and Fish Canyon Tuff zircons. From this $\mathrm{He}$ raw dates are calculated from the methods based on Ketcham et al. (2011).

Raw dates are corrected for alpha ejection. When the decay of $U$, Th, and Sm takes place the alpha daughter particles shoot out about $20 \mu \mathrm{m}$ from the parent nuclides. This alpha ejection has the probability to release the $4 \mathrm{He}$ atom, or alpha particle, out of the crystal. To account for this loss an alpha ejection correction must be made to the raw calculated dates, determined by the size and shape of the crystal and an assumption that levels of $U$ and Th are uniformly distributed about the crystal (Flowers et al. 2009). Uncertainties are reported with the corrected date based on total U, Th, Sm, and He levels within $2 \sigma$ standard deviation.

\section{Results:}

Out of the seven total samples that were processed and separated, only four of these samples produced quality apatites and zircons. Two samples, the Fig Tree granite (BWJ18-002) and the Chillerma granite (BWJ18-081) yielded apatite and zircon that gave reproducible dates. Five apatites and three zircons from the Fig Tree granite were analyzed along with eight apaties and three zircons from the Chillerma granite. In addition, three zircons were analyzed from the Callina Super Suite granite (BWJ18-031) and three apatites were analyzed from the Carlindi granite (BWJ18-078). 
In the Fig Tree Granite, the Apatite (AHe) dates range from about 350 to $435 \mathrm{Ma}$ and Zircons ( $\mathrm{ZHe}$ ) range from about 310 to $350 \mathrm{Ma}$. And in the Chillerma Granites AHe dates range from about 345 to $410 \mathrm{Ma}$ and ZHe range from about 420 to $440 \mathrm{Ma}$. In the Callina Super Suite, zircon ( $\mathrm{ZHe}$ ) dates range from about 230 to $340 \mathrm{Ma}$. and in the Carlindi granite results were inconclusive with apatite $(\mathrm{AHe})$ dates ranging from 415 to 1070 Ma with no clear average. Of all of these samples, two apatite minerals from the Carlindi, one apatite from the Chillerma, and one zircon are disregarded. There appear to be micro-inclusions not seen during hand picking that potentially influenced the levels of $\mathrm{U}, \mathrm{Th}$, and $\mathrm{Sm}$ to produce unusually high data levels thus skewing the calculated date.

Radiation damage of crystals affects the retention of $\mathrm{He}$ and because of this, it affects the temperature sensitivity of the apatites and zircons. To account for this, effective uranium $(\mathrm{eU}=[\mathrm{U}]+0.235[\mathrm{Th}])$ concentration is used as an intermediary tracker to radiation damage, it is a parameter that weighs the decay of the two parent atoms against their alpha productivity (Flowers et al., 2007). Common practice in the (U$\mathrm{Th} / \mathrm{He}$ thermochronology community is to compare these levels of eU to the corrected dates as seen in the plots below (Fig. 15 \& 16). Radiation damage in apatites increases the closure temperature which affects both eU and analyzed date positively for samples that have experienced long histories (Shuster et al., 2006; Flowers et al., 2009).

Damage to the zircon is a bit different, as it accumulates damage, the He closure temperature increases until it reaches an alpha dose threshold of about $150 * 10^{16} \alpha / g$, after this the retention of $\mathrm{He}$ is lost and closure temperature decreases (Guenthner et al., 2013; Ketcham et al., 2013). Another concern is that at higher temperatures, the 
radiation damage can be annealed thus reversing the effects of He diffusivity in accumulation (Baughman, 2017). Factoring in the damage, annealing, and alpha ejection correction, we use a conservative $20 \%$ uncertainty for reporting eU values. Reasoning for this uncertainty is grounded in the maximum eU difference that is calculated from the volumes of the grains (Baughman et al., 2017). 
Table 2: (U-Th)/He analysis results of apatite (aHe) and zircon (zHe) samples

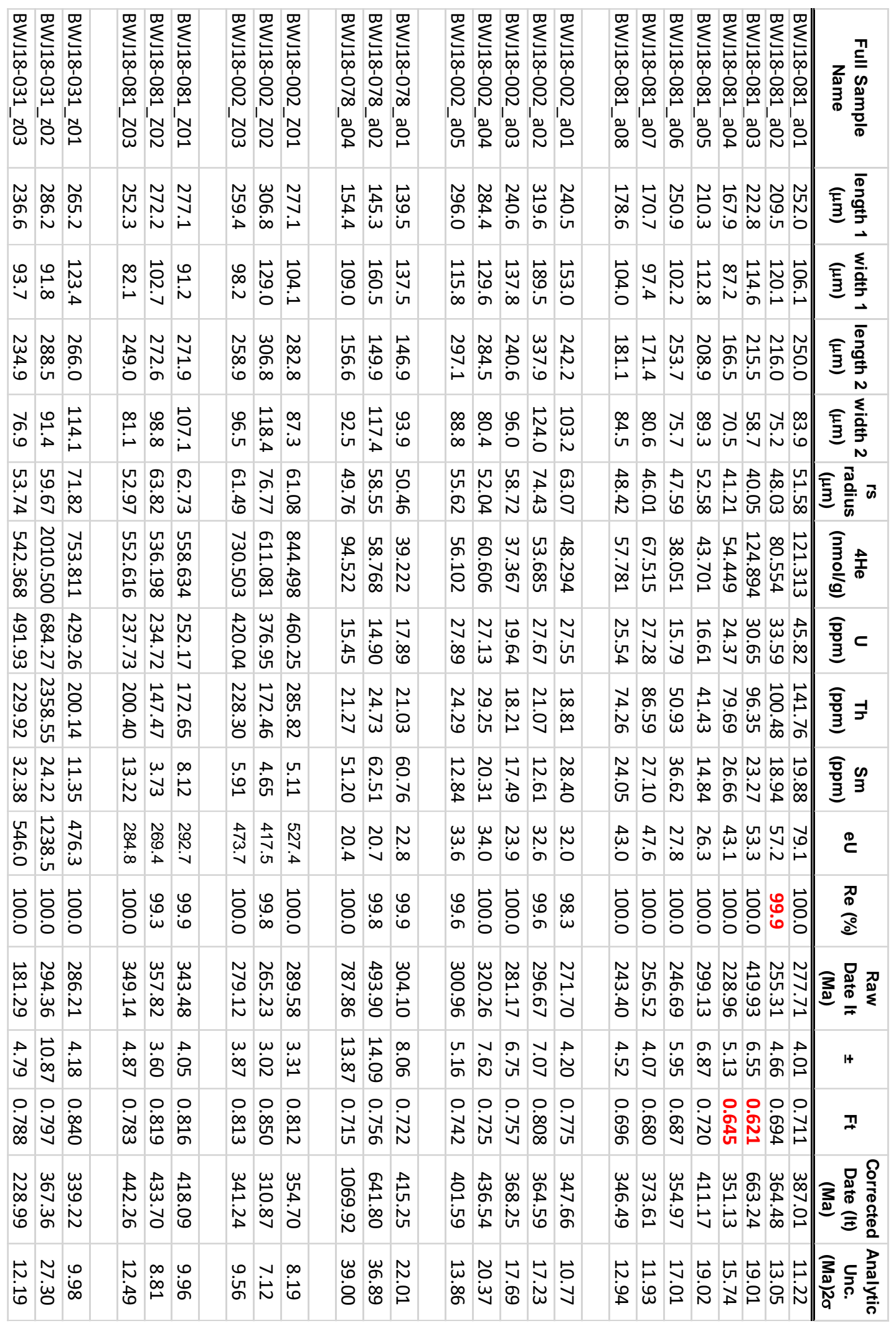




\section{AHe Date vs eU}

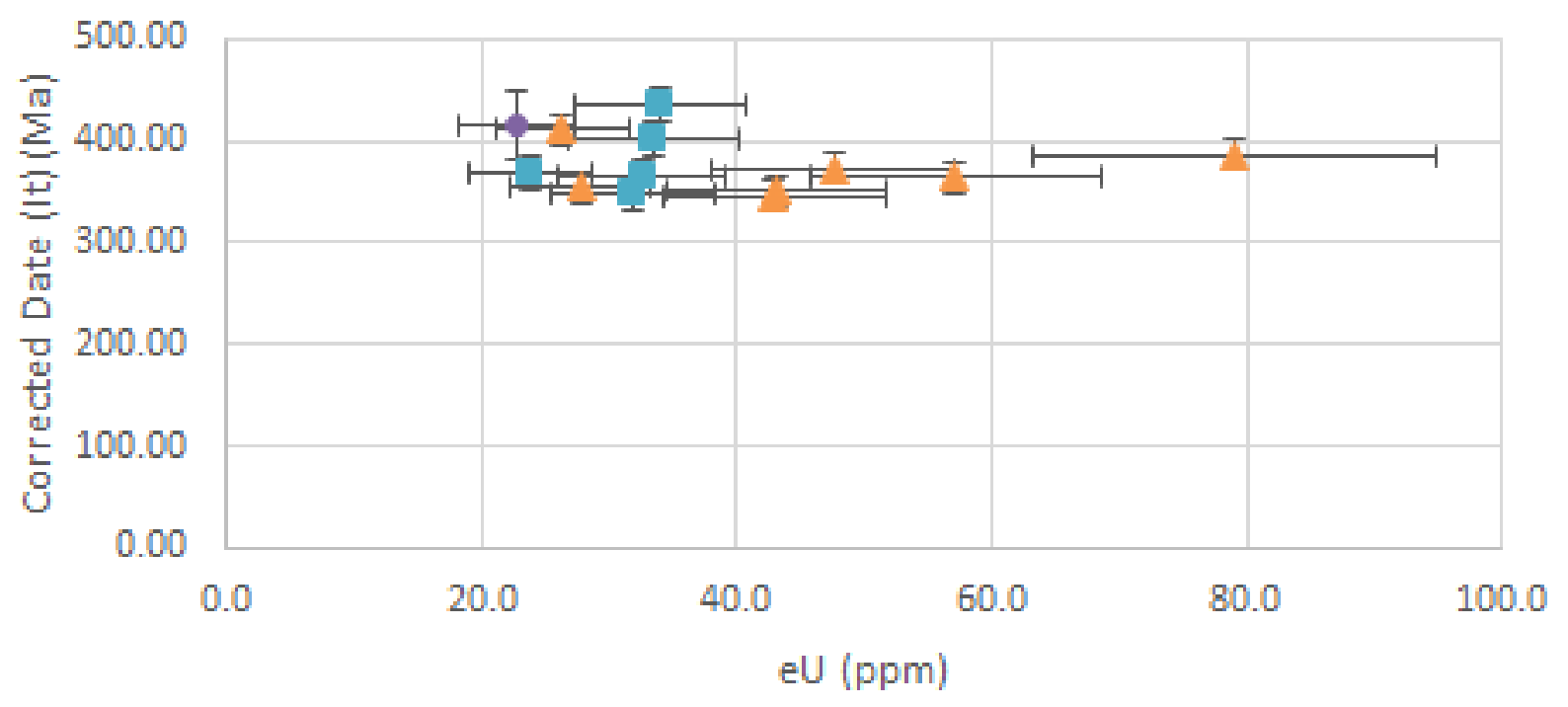

A BWJ18-081 apatites $\quad$ BWJ18-002 apatites BWJ18-078 apatites

\section{ZHe Date vs eU}

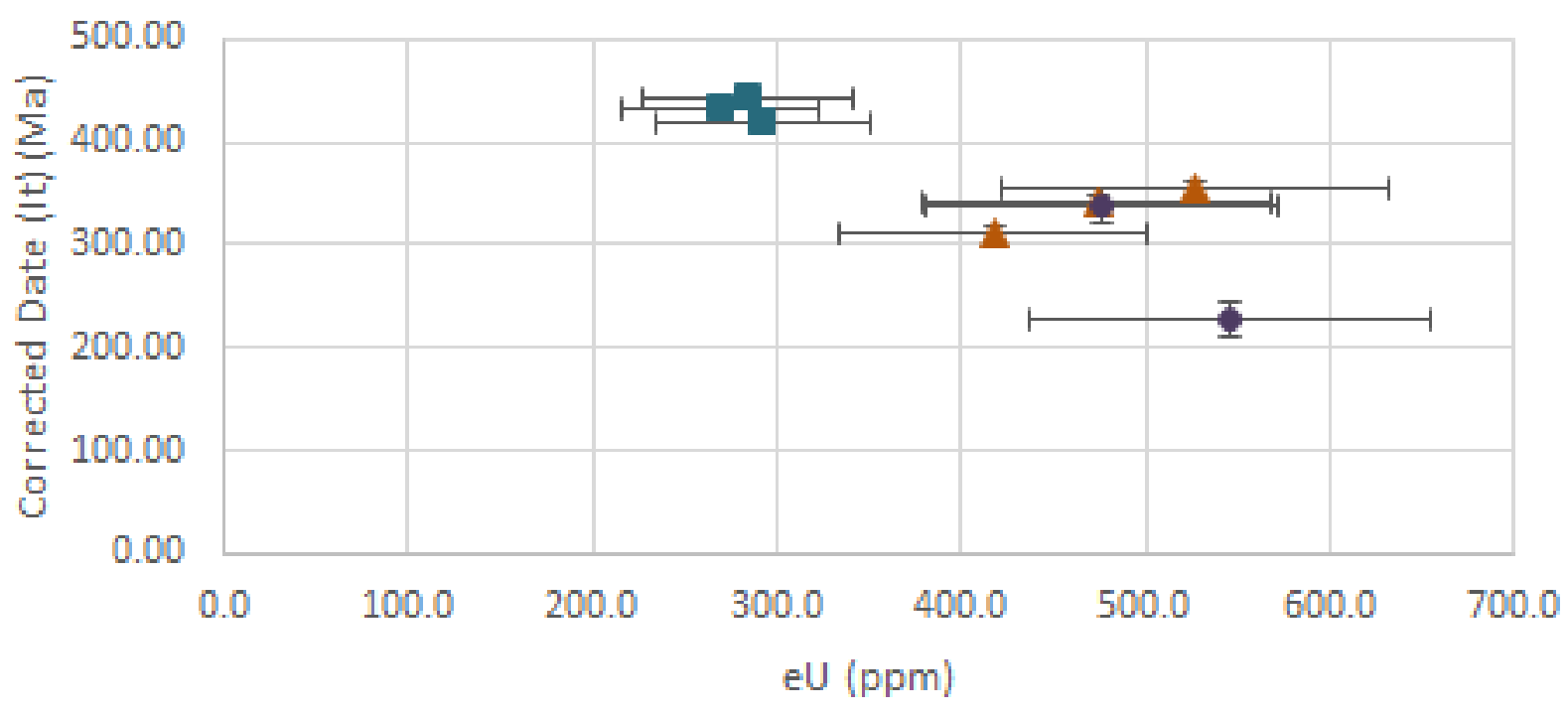

$\Delta$ BWJ18-002 zircons a BWJ18-081 zircons • BWJ18-031 zircons

Figure 15: Plot of apatite aHe (A) and zircon zHe (B) displaying corrected date (Ma) vs. eU levels in parts per million 

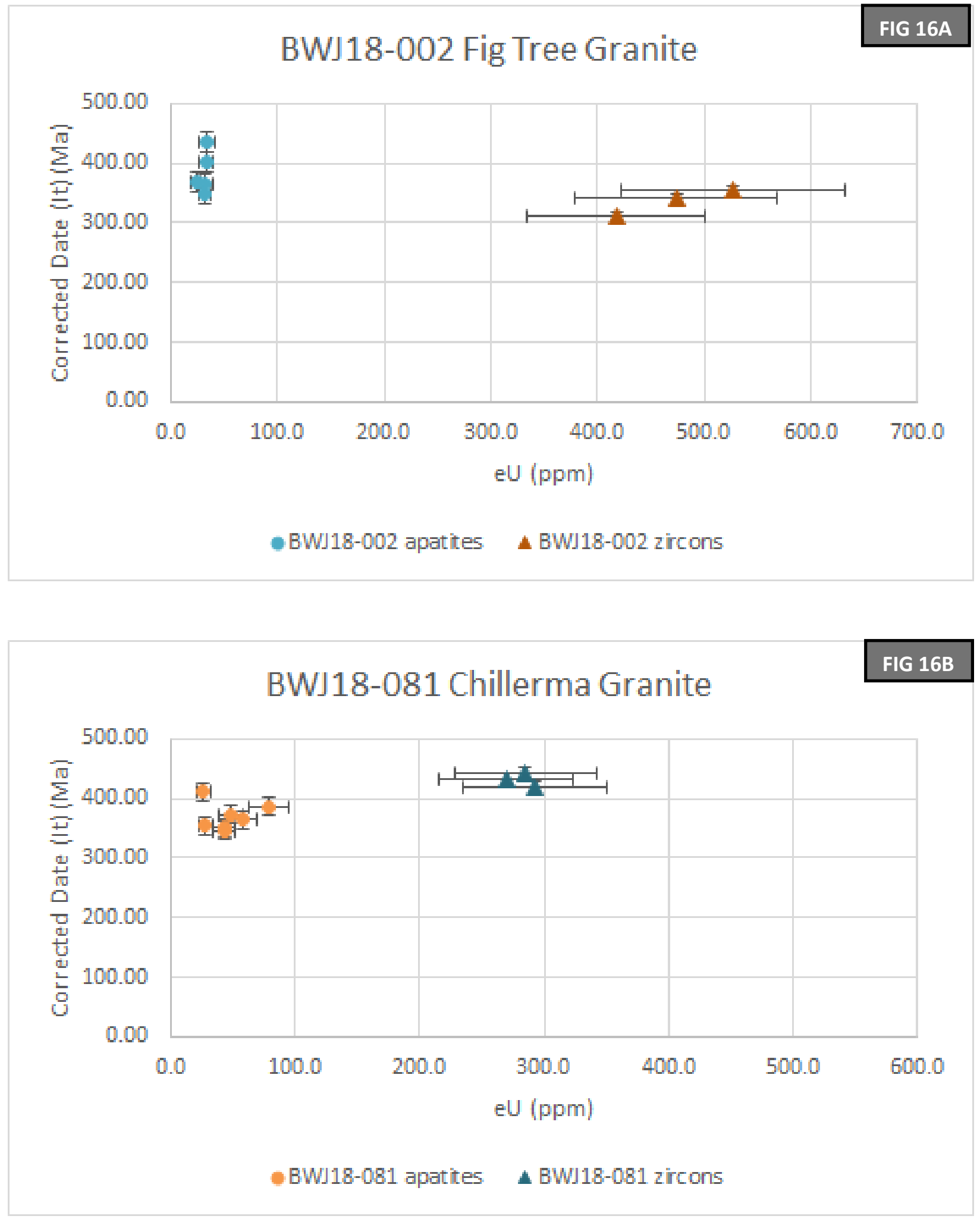

Figure 16: Plot of apatite aHe and zircon zHe from Fig Tree (A) and Chillerma (B) samples displaying corrected date (Ma) vs. eU levels in parts per million 


\section{Discussion:}

It is not uncommon with rock samples of this age to measure AHe and ZHe data points with widespread scatter, due to the long geologic history and potential for reburial, reheating, or other tectonic events. This is not the case for the Pilbara samples in this study. The AHe and ZHe dates produced after (U-Th)/He Thermochronology analysis have good agreement and estimate very similar cooling ages seen on the plots. (Figs. $15 \& 16$ ).

The reproducibility of these samples and the overlap of the AHe and $\mathrm{ZHe}$ dates provide evidence for a regional cooling event that occurred $\sim 340-440 \mathrm{Ma}$. Such an event would have caused both minerals to drop below their closure temperatures and begin retaining ${ }^{4} \mathrm{He}$ at that time.

The link between closure temperature of the mineral sample and a cooling event taken place can be explained with geothermal gradient (Fig. 17). This is a rate of increasing temperature with respect to an increase in depth into the Earth's crust and interior. Typically, at the near surface this gradient is $\sim 25-30^{\circ} \mathrm{C} / \mathrm{km}$ on average. So for a mineral in our sample to reach $\sim 80-100^{\circ} \mathrm{C}$ this means it would likely be within $\sim 3-4 \mathrm{~km}$ of the Earth's surface. A possible explanation for such a cooling episode is an uplift event followed by

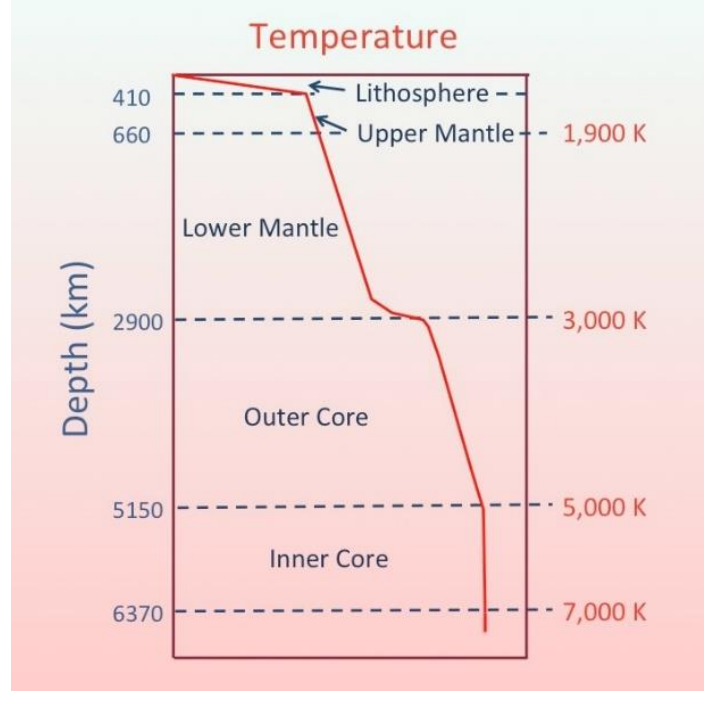

Figure 17: Schematic of the geothermal gradient of Earth's interior (Adapted from Boehler, R., 1996) 
an erosional event that removed rock layers that were on top of the formed minerals bringing the Earth's surface down.

Additionally, Mid to Late Mesozoic riverine deposits that overlie the Chillerma Granite sample, indicate that this sample was exhumed to the surface by this time (Fig. 7B). Moreover, the consistency of the $\mathrm{AHe}$ and $\mathrm{ZHe}$ data suggests that they were not reset by reheating after $440 \mathrm{Ma}$. This implies that if reburial did occur that it was not deep enough to reset sampled minerals.

It is possible that regional events such as rifting, extension, uplift and erosion, could explain the cooling indications we found in the apatite and zircon minerals.

During this age window, Australia was being amalgamated into Gondwana and Pangaea. Events happening around this time include: The Larapinta Seaway rifting (490-460 Ma), Harts Range orogen inversion (450$410 \mathrm{Ma})$, Strangways Range
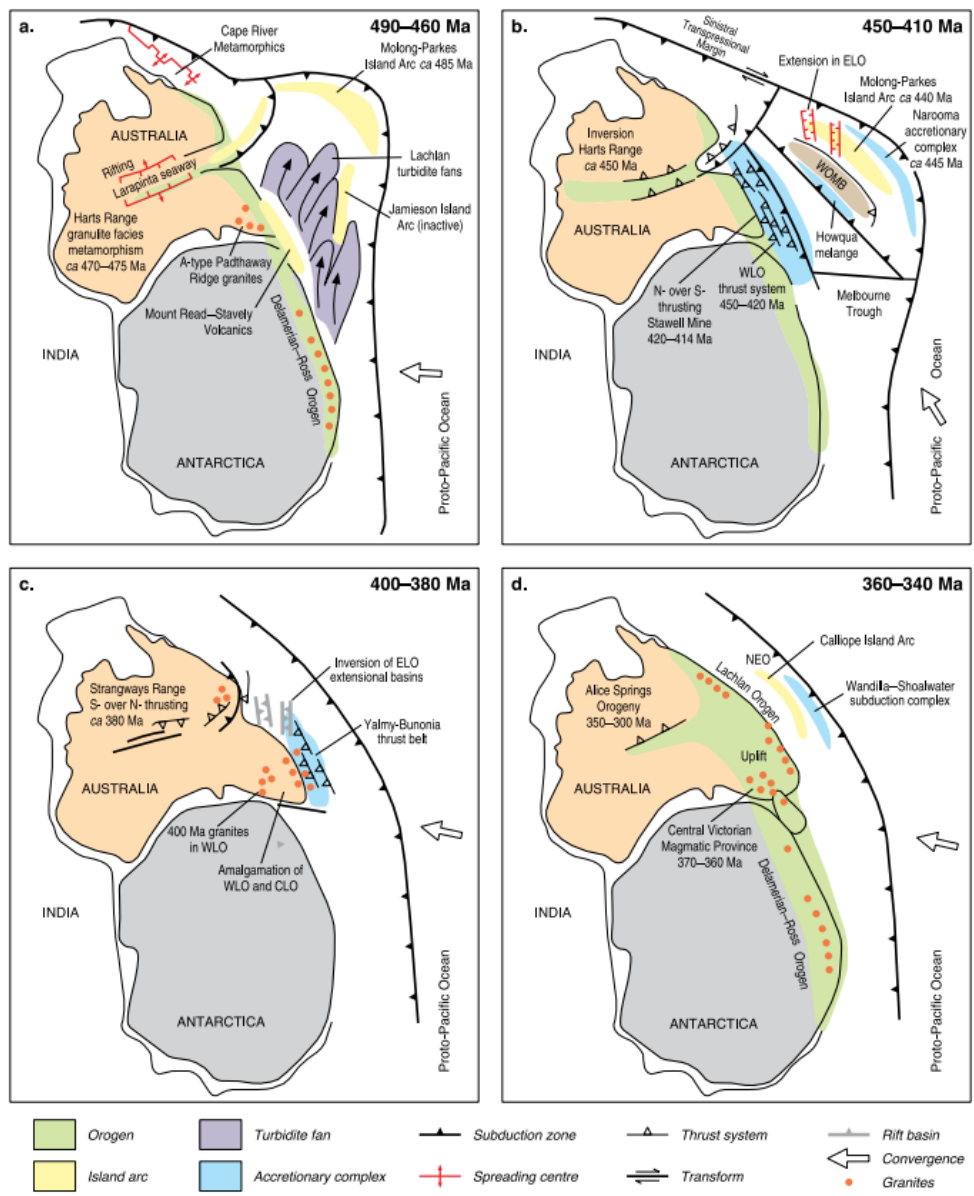

Figure 18: From Blewett's 2012 Shaping a Nation: A Geology of Australia, depicting the extension, rifting, and uplift events from 490-340 Ma. 
thrusting (400-380 Ma), and the Alice Springs Orogeny (360-340 Ma) (Fig. 18) (Blewett, 2012).

Previous low temperature thermochronology using apatite fission-track (AFT) technique suggests that cooling of a region $\sim 200 \mathrm{~km}$ south of the Chillerina Granite sample, occurred around $320 \mathrm{Ma}$ (Weber et al., 2005). Interestingly, other AFT studies of Australia have similar recorded ages mostly grouped in a range from about 200-400 Ma. (Fig. 19) (Gleadow et al., 2002).

After looking at these data and the work done here in my study, I hypothesis the Alice Springs Orogeny to be the best possible explanation for the cooling event signature seen in the results. The $\sim 360-340$ Ma uplift event falls right in line with the (UTh)/He dates of both aHe and zHe samples found my analysis. The majority of cooling ages are just under $400 \mathrm{Ma}$, suggesting close correlation in time with the Alice Springs event.

The Alice Springs orogeny is a reactivation of previously established normal faults (Blewett, 2012). Fairly distant convergence may have provided necessary tectonic stress to cause uplift and erosion, perpendicular to the direction of convergence in an analogous way to the Uintah Mountains of North America. Thus, while the Alice Springs orogeny is relatively far from a plate boundary, the coincidence of cooling ages



Figure 19: From Gleadow et al., 2002, showing apatite fission track data from around Australia. 
with this mechanism for uplift suggest it to be a possible geologic cause of Paleozoic cooling. In addition, close age ranges found in the Weber et al. and Gleadow et al. studies from AFT methods. The comparison of these studies implies that the Pilbara Craton had a dynamic and protracted Paleozoic exhumation history.

\section{Conclusion:}

The Pilbara Craton is one of the best preserved and pristine fragments of Archean crust on the planet. The Pilbara has proved to have many key observations into the Archean geologic setting of early Earth, however its more recent Phanerozoic history is not as well known. This is in part due to the lack of published work on the area, as well as the region's substantial age and complexity. The samples I analyzed using (U-Th)/He thermochronology methods imply a regional cooling event around 340-440 Ma. In addition, observations from the Callwa Formation, a JurassicCretaceous sediment layer that unconformably overlies my Chillerma Granite sample (Fig. 7B), indicate that the Pilbara craton basement in this region was exhumed to the surface by Jurassic-Cretaceous time. We also know that reburial to temperatures greater than $80-100^{\circ} \mathrm{C}$ could not have taken place as radiogenic He would have been lost from the crystals, causing the dates to be younger than observed. It would be intriguing to examine more low temperature data or other dating techniques of the Phanerozoic history of the Pilbara and Western Australia. Continuing work into the three remaining un-analyzed samples would prove valuable to a larger picture of the region. 


\section{Reference list}

Ahmad, I., Mondal, M.E.A., and Satyanarayanan, M., 2016, Geochemistry of Archean metasedimentary rocks of the Aravalli craton, NW India: Implications for provenance, paleoweathering and supercontinent reconstruction: Journal of Asian Earth Sciences, v. 126, p. 58-73, doi:10.1016/j.jseaes.2016.05.019.

Baughman, J.S., Flowers, R.M., Metcalf, J.R., and Dhansay, T., 2017, Influence of radiation damage on titanite He diffusion kinetics: Geochimica et Cosmochimica Acta, v. 205, p. 50-64, doi:10.1016/j.gca.2017.01.049.

Blewett, R. (Ed.), 2012, Shaping a Nation: A Geology of Australia: ANU Press, doi:10.22459/SN.08.2012.

Boehler, R., 1996, MELTING TEMPERATURE OF THE EARTH'S MANTLE AND CORE: Earth's Thermal Structure: Annual Review of Earth and Planetary Sciences, v. 24 , p. 15-40, doi:10.1146/annurev.earth.24.1.15.

Fairbridge, R.W., and Finkl, C.W., 1980, Cratonic Erosional Unconformities and Peneplains: The Journal of Geology, v. 88, p. 69-86, doi:10.1086/628474.

Farley, K.A., 2002, (U-Th)/He Dating: Techniques, Calibrations, and Applications: Reviews in Mineralogy and Geochemistry, v. 47, p. 819-844, doi:10.2138/rmg.2002.47.18.

Flowers, R.M., Shuster, D.L., Wernicke, B.P., and Farley, K.A., 2007, Radiation damage control on apatite (U-Th)/He dates from the Grand Canyon region, Colorado Plateau: Geology, v. 35, p. 447, doi:10.1130/G23471A.1.

Gleadow, A.J.W., Kohn, B.P., Brown, R.W., O'Sullivan, P.B., and Raza, A., 2002, Fission track thermotectonic imaging of the Australian continent: Tectonophysics, $v$. 349, p. 5-21, doi:10.1016/S0040-1951(02)00043-4.

Guenthner, W.R., Reiners, P.W., Ketcham, R.A., Nasdala, L., and Giester, G., 2013, Helium diffusion in natural zircon: Radiation damage, anisotropy, and the interpretation of zircon (U-Th)/He thermochronology: American Journal of Science, v. 313, p. $145-198$, doi:10.2475/03.2013.01.

Ketcham, R.A., Guenthner, W.R., and Reiners, P.W., 2013, Geometric analysis of radiation damage connectivity in zircon, and its implications for helium diffusion: American Mineralogist, v. 98, p. 350-360, doi:10.2138/am.2013.4249.

Ketcham, R.A., Gautheron, C., and Tassan-Got, L., 2011, Accounting for long alphaparticle stopping distances in (U-Th-Sm)/He geochronology: Refinement of the baseline case: Geochimica et Cosmochimica Acta, v. 75, p. 7779-7791, doi:10.1016/j.gca.2011.10.011. 
Kranendonk, M.J.V., 2002, Geology and Tectonic Evolution of the Archean North Pilbara Terrain, Pilbara Craton, Western Australia: Economic Geology, v. 97, p. 695-732, doi:10.2113/97.4.695.

Metcalf, J.R., and Flowers, R.M., In Press, (U-Th)/He Chronology, Encyclopedia of Geology, 2nd Edition

Nijman, W., Kloppenburg, A., and de Vries, S.T., 2017, Archaean basin margin geology and crustal evolution: an East Pilbara traverse: Journal of the Geological Society, v. 174, p. 1090-1112, doi:10.1144/jgs2016-127.

Rogers, J.J.W., 1996, A History of Continents in the past Three Billion Years: The Journal of Geology, v. 104, p. 91-107, doi:10.1086/629803.

Saha, L., Frei, D., Gerdes, A., Pati, J.K., Sarkar, S., Patole, V., Bhandari, A., and Nasipuri, P., 2016, Crustal geodynamics from the Archaean Bundelkhand Craton, India: constraints from zircon U-Pb-Hf isotope studies: Geological Magazine, v. 153, p. 179-192, doi:10.1017/S0016756815000692.

Smithies, R.H., A.H. Hickman, and D.R. Nelson, 1999, New constraints on the evolution of the Mallina Basin, and their bearing on relationships between the contrasting eastern and western granite-greenstone terranes on the Archaean Pilbara Craton, Western Australia: Precambrian research, v. 94, p.11-28.

Shuster, D.L., Flowers, R.M., and Farley, K.A., 2006, The influence of natural radiation damage on helium diffusion kinetics in apatite: Earth and Planetary Science Letters, v. 249, p. 148-161, doi:10.1016/j.epsl.2006.07.028.

Wacey, D., 2010, Stromatolites in the $\sim 3400$ Ma Strelley Pool Formation, Western Australia: Examining Biogenicity from the Macro- to the Nano-Scale: Astrobiology, v. 10, p. 381-395, doi:10.1089/ast.2009.0423.

Weber , U.D., Kohn, B.P., and Gleadow, A.J.W., 2004, MUCCAN BATHOLITH, EASTERN PILBARA, WESTERN AUSTRALIA: CRC LEME,.

Weber, U.D., Kohn, B.P., Gleadow, A.J.W., and Nelson, D.R., 2005, Low temperature Phanerozoic history of the Northern Yilgarn Craton, Western Australia: Tectonophysics, v. 400, p. 127-151, doi:10.1016/j.tecto.2005.03.008.

Zegers, T.E., J.R. Wijbrans, and S.H. White, 1999, 40Ar/39Ar age constraints on tectonothermal events in the Shaw area of the eastern Pilbara granite-greenstone terrain (W Australia): $700 \mathrm{Ma}$ of Archean tectonic evolution: Tectonophysics, v. 311, p.45-81. 